\title{
Food Habits of Dabbling Ducks During Fall Migration in a Prairie Pothole System, Heron Lake, Minnesota
}

\author{
RyAn M. Wersal ${ }^{1}$, Brock R. McMillan ${ }^{2}$, and JOHN D. MAdSEN ${ }^{1}$ \\ ${ }^{1}$ GeoResources Institute, Mississippi State University, Box 9652, Mississippi State, Mississippi 39762, USA [corresponding \\ authors] \\ ${ }^{2}$ Department of Biological Sciences, Minnesota State University, Mankato, 242 Trafton Science Center S, Mankato, Min- \\ nesota 56001 USA
} Wersal, Ryan M., Brock R. McMillan, and John D. Madsen. 2005. Food habits of dabbling ducks during fall migration in a
prairie pothole system, Heron Lake, Minnesota. Canadian Field-Naturalist 119(4): 546-550.

We conducted an analysis of dabbling duck food habits in the fall of 2002 and 2003 in the Heron Lake system. Gizzard contents of hunter-harvested birds were analyzed using the percent aggregate volume method to determine what food items were consumed and in what quantity. Curltop Ladysthumb (Polygonum lapathifolium) was the food item consumed most often $(82.2 \%)$ and in the greatest volume $(34.2 \mathrm{ml})$. Sago Pondweed (Stuckenia pectinata) was the only food item of which multiple plant parts were consumed. However, the seeds and tubers only comprised 1.27 and 0.07 of the total aggregate percent.

Key Words: Food habits, waterfowl, gizzard contents, aggregate volume, submersed macrophytes, Curltop Ladysthumb, Polygonum lapathifolium, Sago Pondweed, Stuckenia pectinata.

The food habits of waterfowl are often diverse and vary throughout a state and flyway (Havera 1999). It is necessary to have a firm understanding of food use of waterfowl for effective management and to provide a diversity of high quality wetland habitat (Havera 1999). Quality habitat (abundant and available) is the most important ecological component affecting waterfowl populations which includes the essential elements of food, cover, and water (Baldassarre and Bolen 1994). Wetland habitats are crucial in providing food that waterfowl prefer instead of areas where they have to feed on only what is available (Havera 1999). Waterfowl consume a wide variety of vegetation of which submersed macrophytes constitute a large fraction of the total food items consumed (Martin and Uhler 1939; Havera 1999).

Submergent macrophyte communities are a direct source of waterfowl food and indirectly serve as an environment for aquatic macroinvertebrates (Baldassarre and Bolen 1994). Submersed macrophytes can comprise the bulk of food items consumed by migrating waterfowl (Martin and Uhler 1939). For example, Curlyleaf Pondweed (Potamogeton crispus) on average yields $140 \mathrm{~kg} / \mathrm{ha}$ of seed per season, or enough to sustain 2470 Mallards (Anas platyrhynchos) per hectare per day (Hunt and Lutz 1959). The pondweeds (Potamogeton and Stuckenia spp.) ranked first, by volume, as food consumed by 18 species of waterfowl (Martin and Uhler 1939).

Of the pondweeds, $S$. pectinata is said to be one of the most sought after food plants by waterfowl (Kantrud 1990). Stuckenia pectinata is probably the most important single waterfowl food plant on the continent and is responsible for about half, or more, of the total food percentage credited to the genus Potamogeton [Stuck- enia] (Martin and Uhler 1939). As a food item, S. pectinata can form a significant portion of foods found in gizzards of fall staging populations, pre-molting birds, flightless molting ducks, and ducklings (Chura 1961; Hay 1974; Keith and Stanislawski 1960).

Historically, the Heron Lake system has been an important staging area for fall migrating waterfowl due to its extensive beds of aquatic macrophytes. An account from 1906 reported over 700000 Canvasbacks (Aythya valisineria) on North Heron Lake feeding on mats of Wild Celery (Vallisneria americana) (Berry and German 1999). The Wild Celery disappeared in 1922 as a result of the Common Carp (Cyprinus carpio) (Berry and German 1999) and today sago pondweed is the only submersed macrophyte found in the Heron Lake system (Case 2003; Case and Madsen 2004). Poor water quality is attributed to the lack of macrophyte growth, a likely result of runoff from the high percentage of agricultural land surrounding the lakes and point source pollution including sewage and industrial effluent from nearby cities (Case 2003; Case and Madsen 2004). The Heron Lake system also has high sediment resuspension and increased turbidity due to shallow water and a large fetch (Case 2003; Case and Madsen 2004).

Although the Heron Lake system is in a degraded state, it is still used by migrating waterfowl as it is one of the largest shallow lake systems in the region. Due to its continued importance to waterfowl we conducted a preliminary investigation of the food habits of fall migrating dabbling ducks staging in the Heron Lake system in October of 2002 and 2003. The primary objective was to determine the principal foods utilized by fall migrating dabbling ducks, with particular interest to aquatic macrophytes, especially sago pondweed. 


\section{Methods}

Site Description

The Heron Lake system is located in Jackson County, Minnesota $\left(43.72333^{\circ} \mathrm{N} 95.2325^{\circ} \mathrm{W}\right)$ and comprises four lakes; of which South Heron and North Heron Lakes were used in this study. The four lakes have a mean depth of less than $1.5 \mathrm{~m}$ and a combined surface area of approximately 3200 hectares. South Heron Lake (1220 ha) can be divided into a north bay and a south bay by differing sediment characteristics (Case and Madsen 2004). South Heron Lake is connected to North Heron Lake via Division Creek located in the northern most part of the lake. North Heron Lake (1350 ha) is a flat, shallow lake with little change in depth from one end to the other. North Marsh (430 ha) is a small shallow water body located at the northern edge of North Heron Lake. Birds harvested on North Marsh were included in North Heron Lake due the close proximity of the lakes. Duck Lake (190 ha) was not included in this study due to the lack of public access for hunters.

\section{Food Habit Collection}

Hunters from South Heron and North Heron Lakes (including North Marsh) were asked to collect the gizzards from their harvested birds during each hunting day in 2002 and 2003. The harvested samples were placed in 1.06-1 Whirl-pak bags filled with a 75\% ethyl alcohol solution. A waterproof label was affixed to each bag to record the lake, the species and sex of the bird, and the date of harvest. The collected samples were stored in a refrigerator at approximately $4^{\circ} \mathrm{C}$ until processing.

In the lab, each gizzard was opened and its contents washed through a series of standard testing sieves. Number 20 (850 micrometer), number 35 (500 micrometer), and number 140 (106 micrometer) sieves were used to separate food items by size. Samples were processed using the dry volumetric method (Rogers and Korschgen 1966). Each food item was placed in plastic measuring dishes and dried at $55^{\circ} \mathrm{C}$ for 48 hours in a constant temperature oven. We summarized food items by species of waterfowl. Organic and inorganic materials were separated using a dissecting microscope. Items within a sample were separated according to species of plant or animal.

Volumetric measurements were made using a microsyringe (used for small food items and items found in small quantities), $10 \mathrm{ml}$, or $25 \mathrm{ml}$ graduated cylinders (Rogers and Korschgen 1966). We placed food items into the micro-syringe or graduated cylinder and compressed slightly with a small dowel to remove any air pockets. Once the air had been removed we recorded the volume of that food. We identified plant items to genus level (if postmortem digestion had not rendered the item unidentifiable) and macroinvertebrates were identified to family. The identification of seeds was made using descriptions and diagrams by Martin (1951, 1954) (for Polygonum and Potamogeton spp.), the text by Martin and Barkley (1961), and the taxo- nomic key by Crow and Hellquist (2000). Seed identifications were verified by a taxonomic expert at Mississippi State University. Scientific and common names for plant species followed the Checklist of North American Plants for Wildlife Biologists by Scott and Wasser (1980). We identified invertebrates using the taxonomic key by Pennak (1978).

\section{Data Analysis}

We used percent occurrence to describe the frequency of a food item in the samples and to assess the relative use of a food item by waterfowl. We expressed volumes of food items as the percent of aggregate volume (Martin et al. 1946). Aggregate volume quantifies the relative importance of food types as it addresses the amount of a food item consumed by waterfowl. Individuals from the same species were aggregated per food item and the sum of each food item was then divided by the total volume of food consumed by all individuals.

Percent Aggregate Volume was calculated as (1):

$\sum$ (volume of food item $\mathrm{i}_{\mathrm{i}}$ across all animals in the sample) $\times 100$ Total volume of all foods consumed in the sample

\section{Results}

\section{Harvested Waterfowl}

We collected 63 gizzards from fall migrating waterfowl, 46 gizzards in 2002 and 17 gizzards in 2003 (Table 1). Blue-winged Teal (See Table 1 for scientific names) comprised the majority of the samples taken, followed by Green-winged Teal, Mallards, and Wood Ducks. Other species represented included the Northern Shoveler and Northern Pintail.

Plant material comprised $99.4 \%$ of the total aggregate percent of food items collected (Table 2). Polygonum lapathifolium seeds made up the largest aggregate percent of food items collected from waterfowl in this wetland system. Potamogeton pusillus seeds ranked second in total aggregate percent followed by the seeds of Rice Cutgrass (Leersia oryzoides) and P. dichotomiflorum. Soybeans (Glycine max) appeared to rank higher in aggregate percent than $P$. dichotomiflorum; however, they were found in large amounts only in the few Wood Ducks harvested in this study. The fact that it was only found in a few individuals overestimated its volumetric importance.

Animal matter constituted only $(0.5 \%)$ of the total aggregate percent (Table 2). Water boatmen (Corixidae) were consumed more frequently and in the greatest amount. Blue-winged Teal accounted for the majority of the midges (Chironomidae) consumed. Other dabbling ducks that consumed invertebrates include Green-winged Teal, Mallards, and Gadwall which consumed Planorbidae, Physidae, and Plecoptera invertebrates, respectively.

\section{Discussion}

Polygonum lapathifolium was the most important food consumed by dabbling ducks; it occurred in the 
TABLE 1. Species list of dabbling ducks harvested in the Heron Lake system during the fall hunting seasons of 2002 and 2003.

\begin{tabular}{lrcccc}
\hline \hline Species & $\mathrm{n}$ & \% of Sample & Female & Male & Unknown \\
\hline Blue-winged Teal (Anas discors) & 27 & 42.8 & 9 & 1 & 17 \\
Green-winged Teal (Anas crecca) & 14 & 22.2 & 7 & 4 & 3 \\
Mallard (Anas platyrhynchos) & 13 & 20.6 & 8 & 5 & 0 \\
Wood Duck (Aix sponsa) & 4 & 6.3 & 1 & 1 & 1 \\
Northern Shoveler (Anas clypeata) & 2 & 3.1 & 1 & 1 & 0 \\
Gadwall (Anas strepera) & 2 & 1.1 & 0 & 0 & 0 \\
Northern Pintail (Anas acuta) & $\mathbf{6 3}$ & $\mathbf{1 0 0 . 0}$ & $\mathbf{2 7}$ & $\mathbf{1 4}$ & $\mathbf{2 2}$ \\
Total & & & & \\
\hline \hline
\end{tabular}

TABLE 2. Gizzard contents ( \pm 1 SE) of harvested dabbling ducks in the Heron Lake system during October of the 2002-2003 hunting seasons. Food items without a standard error had less than two birds containing that food item. All food items are seeds unless otherwise noted.

\begin{tabular}{|c|c|c|c|}
\hline Food Item & Frequency $(\%)$ & Volume (ml) & Aggregate (\%) \\
\hline Amaranthus spp. & 46.77 & $0.45 \pm 0.15$ & $0.73 \pm 0.15$ \\
\hline Bidens spp. & 9.68 & $0.05 \pm 0.02$ & $0.08 \pm 0.01$ \\
\hline Carex spp. & 40.32 & $0.24 \pm 0.06$ & $0.39 \pm 0.06$ \\
\hline Ceratophyllum demersum & 37.10 & $0.67 \pm 0.18$ & $1.09 \pm 0.18$ \\
\hline Chenopodium spp. & 3.23 & $0.05 \pm 0.02$ & $0.08 \pm 0.01$ \\
\hline Cyperus erythrorhizos & 6.45 & $0.08 \pm 0.02$ & $0.13 \pm 0.02$ \\
\hline Cyperus odoratus & 46.77 & $0.34 \pm 0.03$ & $0.55 \pm 0.03$ \\
\hline Echinochloa crusgalli & 22.58 & $1.29 \pm 0.38$ & $2.10 \pm 0.38$ \\
\hline Eleocharis spp. & 9.68 & $0.01 \pm 0.00$ & $0.02 \pm 0.01$ \\
\hline Glycine $\max$ & 1.61 & 2.80 & 4.57 \\
\hline Leersia oryzoides & 19.35 & $2.75 \pm 0.57$ & $4.49 \pm 0.53$ \\
\hline Lolium spp. & 1.61 & 0.03 & 0.05 \\
\hline Panicum dichotomiflorum & 41.94 & $2.24 \pm 0.88$ & $3.65 \pm 0.88$ \\
\hline Pinus spp. & 1.61 & 0.06 & 0.10 \\
\hline Polygonum lapathifolium & 82.26 & $21.01 \pm 1.73$ & $34.27 \pm 1.73$ \\
\hline Polygonum pennsylvanicum & 14.52 & $0.15 \pm 0.01$ & $0.24 \pm 0.01$ \\
\hline Polygonum persicaria & 8.06 & $0.02 \pm 0.01$ & $0.03 \pm 0.01$ \\
\hline Potamogeton natans & 8.06 & $0.37 \pm 0.09$ & $0.60 \pm 0.09$ \\
\hline Potamogeton pusillus & 58.06 & $5.37 \pm 0.64$ & $8.76 \pm 0.64$ \\
\hline Potamogeton (unidentified) & 11.29 & $0.08 \pm 0.01$ & $0.13 \pm 0.01$ \\
\hline Sagittaria latifolia & 6.45 & $0.80 \pm 0.39$ & $1.31 \pm 0.39$ \\
\hline Scirpus acutus & 41.94 & $2.15 \pm 0.08$ & $3.51 \pm 0.08$ \\
\hline Scirpus fluviatilis & 25.81 & $1.96 \pm 0.30$ & $3.20 \pm 0.30$ \\
\hline Scirpus validus & 17.74 & $0.17 \pm 0.01$ & $0.28 \pm 0.01$ \\
\hline Stuckenia filiformis & 4.84 & $0.42 \pm 0.18$ & $0.69 \pm 0.18$ \\
\hline Stuckenia pectinata & 22.58 & $0.78 \pm 0.08$ & $1.27 \pm 0.08$ \\
\hline Stuckenia pectinata (tuber) & 1.61 & 0.04 & 0.07 \\
\hline Zanichellia spp. & 1.61 & 0.02 & 0.03 \\
\hline Zea mays & 1.61 & 6.80 & 11.09 \\
\hline Setaria spp. & 1.61 & 0.03 & 0.05 \\
\hline Macerated Items & 32.26 & $9.75 \pm 0.35$ & $15.91 \pm 0.35$ \\
\hline Chironomidae & 3.23 & $0.07 \pm 0.01$ & $0.11 \pm 0.01$ \\
\hline Corixidae & 16.16 & $0.12 \pm 0.02$ & $0.20 \pm 0.02$ \\
\hline Physidae & 1.61 & 0.07 & 0.11 \\
\hline Planorbidae & 3.23 & $0.01 \pm 0.00$ & $0.02 \pm 0.01$ \\
\hline Plecoptera & 1.61 & 0.02 & 0.03 \\
\hline Unidentified Invertebrate & 3.23 & $0.03 \pm 0.01$ & $0.05 \pm 0.01$ \\
\hline Total Food & & $61.30 \pm 0.63$ & $100.00 \pm 1.04$ \\
\hline Total Plant & & $60.98 \pm 0.75$ & $99.48 \pm 1.22$ \\
\hline Total Animal & & $0.32 \pm 0.01$ & $0.52 \pm 0.02$ \\
\hline
\end{tabular}


majority of species, and ranked highest in percent aggregate volume. These results concur with a similar study conducted in Illinois where $P$. lapathifolium occurred in $95 \%$ of all Blue-winged Teal gizzards sampled (Havera 1999). Polygonum lapathifolium is widely distributed in the Heron Lake system as noted by vegetation transects (Heron Lake Watershed District, unpublished data) making it readily available as a food source. Stuckenia pectinata was also readily available as a food source as it is the only submersed macrophyte found in the Heron Lake system (Case and Madsen 2004). It had a frequency of occurrence of $74.5 \%$ and $46.8 \%$ for North Heron and South Heron Lakes in 2001 (Case and Madsen 2004). Likewise, in a similar study $S$. pectinata had a frequency of occurrence of $77.6 \%$ and $52.8 \%$ for South Heron Lake in 2002 and 2003, respectively; as well as $26.5 \%$ in North Heron Lake during 2003 (Wersal 2004). Stuckenia pectinata was the only item that dabbling ducks consumed multiple parts of the plant. Seeds and tubers were found in gizzards analyzed in this study indicating that $S$. pectinata was utilized as a source of food for dabbling ducks. Kantrud (1986) estimated that a single S. pectinata dominated lake could support a large percentage of the continental migrating waterfowl population for a month during fall staging.

The reduced abundance of $S$. pectinata observed in the Heron Lake system in 2003 may have shifted feeding to other areas of the system where other food items were more abundant. "Superior availability after all is the guiding principle in the choice of foods by birds" (McAtee 1918). Most dabbling species are non-selective in their feeding habits and feed primarily on aquatic or moist soil vegetation that is abundant in a given location (Havera 1999). Mallards have not been found to be selective foragers, but consume what is abundant in the area (Nummi 1993). Blue-winged Teal change their diets in relation to varying wetland conditions to take advantage of abundant food resources (Thompson et al. 1992). Northern Pintails have been found to shift their food selection based on availability of food items in a given area (Euliss and Harris 1987).

Analyzing food habits in a given area using gizzards as opposed to esophagus samples may introduce a bias toward hard-bodied food items as a result of the differences in breakdown rates of hard versus softbodied items (Swanson and Bartonek 1970). However, Wright (1959) found that Mallards contained approximately the same food items in their gizzards as they did in their esophagus. Furthermore, the esophagus of hunter-killed waterfowl are most often empty or contain small amounts of food (Drake 1970; Perry and Uhler 1982) resulting in the reliance on gizzards to obtain sufficient sample numbers (Havera 1999). Also, the bias of hard-bodied items may not be as critical in food habit analyses conducted in the fall because animal matter is not as prevalent in the diets of most species of waterfowl, most notably dabbling ducks (Havera 1999).
The dabbling ducks harvested in the Heron Lake system consumed a variety of food items during fall migration. The most observed waterfowl species in the Heron Lake system were Mallards, Blue-winged Teal, Greenwinged Teal, and Canada Geese, an observation supported by the gizzards collected in this study. Diving species still utilize the Heron Lake system; however, not to the extent of dabbling ducks. The decrease in use of the system by diving ducks can be attributed to the reductions in submersed macrophytes within the system.

The results of this study suggest that submersed macrophytes were not as important to dabbling ducks as moist soil vegetation. Dabbling ducks are finding food; however, management should focus on providing more food that ducks prefer such as moist soil vegetation instead of having ducks feed only on what is available. Likewise, improvements in water quality should facilitate increases in S. pectinata populations and the re-establishment of other aquatic macrophytes to provide a diversity of food items for diving species. Future studies in the system should focus attention towards collecting larger sample sizes; analyze changes in food availability based on management within the system; and analyzing esophagus samples to see if differences in food items exist from that of gizzards.

\section{Acknowledgments}

This project was funded by the U.S. Fish and Wildlife Service in cooperation with the Heron Lake Watershed District and the North Heron Lake Game Producers Association. A special thanks to Jason Neyens and Todd Boonstra for their diligent work in sorting through the gizzard samples. Victor Maddox provided verification of seed identifications. Earlier reviews of this manuscript were provided by Eric Dibble, Victor Maddox, and Randy Markl. We would also like to thank those hunters who took the time to collect samples used in this study. Publication number J-10652 of the Mississippi Agriculture and Forestry Experiment Station.

\section{Literature Cited}

Baldassarre, G. A., and E. G. Bolen. 1994. Waterfowl ecology and management. John Wiley and Sons, New York, New York. 609 pages.

Berry, C. R., and D. German. 1999. Revegetation of shallow lakes: A case study of Heron Lake. Minnesota Waterfowl Association, Minneapolis, Minnesota. 127 pages.

Case, M. L. 2003. Environmental factors limiting the success of sago pondweed (Stuckenia pectinata) in the Heron Lake System, Minnesota. M.S. thesis. Minnesota State University, Mankato, Mankato, Minnesota. 82 pages.

Case, M. L., and J. D. Madsen. 2004. Factors limiting the growth of Stuckenia pectinata (Sago Pondweed) in Heron Lake, Minnesota. Journal of Freshwater Ecology 19: 17-23.

Chura, N. J. 1961. Food availability and preferences of juvenile mallards. Transactions of the North American Wildlife and Natural Resources Conference 26: 121-134.

Crow, G. E., and C. B. Hellquist. 2000. Aquatic and Wetland Plants of Northeastern North America. 2 Volumes. University of Wisconsin Press, Madison, Wisconsin 880 pages. 
Drake, S. O., Jr. 1970. Winter foods of mallards of Eufaula National Wildlife Refuge. M.S. thesis. Auburn University, Auburn, Alabama. 117 pages.

Euliss, N. H. Jr., and S. W. Harris. 1987. Feeding ecology of northern pintails and green-winged teal wintering in California. Journal of Wildlife Management 51: 724-732.

Havera, S. P. 1999. Waterfowl of Illinois: status and management. Illinois Natural History Survey Special Publication 21, Illinois. xliii +628 pages.

Hay, R. L. 1974. Molting biology of male gadwalls at Delta, Manitoba. M.S. thesis. University of Wisconsin, Madison, Wisconsin. 20 pages.

Hunt, G. S., and R. W. Lutz. 1959. Seed production by curlleaved pondweed and its significance to waterfowl. Journal of Wildlife Management 23: 405-408.

Kantrud, H. A. 1986. Effects of vegetation manipulation on breeding waterfowl in prairie wetlands, a literature review. U.S. Fish and Wildlife Service Technical Report 3. 15 pages.

Kantrud, H. A. 1990. Sago pondweed (Potamogeton pectinatus L.) A literature review. U.S. Fish and Wildlife Service Resource Publication 176. 89 pages.

Keith, L. B., and R. P. Stanislawski. 1960. Stomach contents and weights of some flightless adult pintails. Journal of Wildlife Management 24: 95-96.

Martin, A. C. 1951. Identifying pondweed seeds eaten by ducks. Journal of Wildlife Management 15: 253-258.

Martin, A. C. 1954. Identifying Polygonum seeds. Journal of Wildlife Management 18: 514-520.

Martin, A. C., and W. D. Barkley. 1961. Seed identification manual. University of California Press, Berkeley and Los Angeles, California. 221 pages.

Martin, A. C., R. H. Gensch, and C. P. Brown. 1946. Alternative methods in upland game bird food analysis. Journal of Wildlife Management 10: 8-12.

Martin, A. C., and F. M. Uhler. 1939. Food of game ducks in the United States and Canada. U.S. Department of Agriculture Technical Bulletin 634. 156 pages.

McAtee, W. L. 1918. Food habits of the mallard ducks of the United States. U.S. Department of Agriculture Technical Bulletin 720. 36 pages.
Nummi, P. 1993. Food niche relationship of sympatric mallards and green-winged teals. Canadian Journal of Zoology 71: 49-55.

Pennak, R. W. 1978. Freshwater invertebrates of the United States, 2nd edition. John Wiley and Sons, New York, New York. 822 pages.

Perry, M. C., and F. M. Uhler. 1982. Food habits and distribution of wintering canvasbacks on Chesapeake Bay. U.S. Fish and Wildlife Service, Patuxent Wildlife Research Center. 50 pages.

Rogers, J. P., and L. J. Korschgen. 1966. Foods of lesser scaups on breeding, migration, and wintering areas. Journal of Wildlife Management 30: 258-264.

Scott, T. G., and C. H. Wasser. 1980. Checklist of North American plants for wildlife biologists. Wildlife Society Publication. 58 pages.

Swanson, A., and J. C. Bartonek. 1970. Bias associated with food analysis in gizzards of blue-winged teal. Journal of Wildlife Management 34: 739-745.

Thompson, J. D., B. J. Sheffer, and G. A. Baldassarre. 1992. Food habits of selected dabbling ducks wintering in Yucatan, Mexico. Journal of Wildlife Management 56: 740744.

Wersal, R. M. 2004. Seasonal biomass, distribution, and waterfowl use of Stuckenia pectinata within the Heron Lake System, Jackson County, Minnesota. M.S. thesis. Minnesota State University, Mankato, Mankato, Minnesota. 91 pages.

Wright, T. W. 1959. Winter foods of mallards in Arkansas. Proceedings of the Annual Conference of the Southeastern Association of the Game and Fish Commission 13: 291295.

Received 29 January 2005

Accepted 1 November 2005

\section{Added in proof}

Wersal, R. M., J. D. Madsen, B. R. McMillan, P. D. Gerard. 2006. Environmental factors affecting biomass and distribution of Stuckenia pectinata in Heron Lake System, Minnesota, USA. Wetlands 26: 313-321. 